\title{
Framework for Assessment of Eco-Safe Rural Roads in Panchase Geographic Region in Central-Western Nepal Hills
}

\author{
Sanjaya Devkota ${ }^{1, * \mathbb{D}}$, Narendra Man Shakya ${ }^{1} \mathbb{D}$ and Karen Sudmeier-Rieux ${ }^{2}$ \\ 1 Department of Civil Engineering, Institute of Engineering, Tribhuvan University, Lalitpur 44700, Nepal; \\ nms@ioe.edu.np \\ 2 Faculty of Geoscience and Environment, Institute of Earth Science, University of Lausanne, CH-1015 \\ Lausanne, Switzerland; karen.sudmeier-rieux@unil.ch \\ * Correspondence: devkotasanjaya@gmail.com
}

Received: 9 April 2019; Accepted: 21 May 2019; Published: 30 May 2019

\begin{abstract}
Rural roads are important for the communities in the hilly areas of Nepal as they introduce livelihood opportunities at the local level, and provide better access to the healthcare, education, and resources. Yet, most of the rural roads in Nepal are unplanned and non-engineered, and these roads are often closed for many months during and after the monsoon. Such roads require huge investments, especially post-monsoon, to clear debris and to keep them operational. In parallel, there is evidence that such roads lead to a large number of slope failures and accelerated sedimentation, which degrade the environment and ecosystem services. To remedy such roadside slope failures, eco-engineering practices were tested and demonstrated in partnership with three communities in the Panchase Region of the Nepal's Central-Western hills. Eco-engineering is a hybrid approach, combining civil engineering works for drainage and slope stability, with the plantation of deep-rooted vegetation. It is one activity contributing to nature-based solutions $(\mathrm{NbS})$ for the sustainable and long-term operation of the rural roads in the Panchase geographic region. This paper describes the inter-disciplinary and community-based research, monitoring, and evaluation methods applied, including the establishment of onsite demonstration plots and rhizotrons in which key performance indicator (KPI) analysis of plant species was performed. The results demonstrated the effectiveness of eco-engineering for reducing risk, while creating ecological co-benefits along rural roads (or eco-safe roads) in hilly areas. Based on this research, an "eco-safe rural road assessment framework" was developed, outlining the systematic process to be followed for the design of eco-safe rural roads for more sustainable road construction and maintenance. The eco-engineering practices which are being promoted by this framework were accepted by communities and could be further implemented by local government bodies and upscaled in other similar hilly areas around the country.
\end{abstract}

Keywords: rural roads; eco-safe roads; eco-engineering; project assessment framework; Nepal

\section{Introduction}

\subsection{Background}

Roads are often the priority investment of local government bodies of Nepal [1]. Investment in roads is considered to bring multiple opportunities for enhancing livelihoods [2]. However, studies showed that, over the period of about 20 years, haphazard construction of rural roads increased exponentially in Nepal [3,4], and these roads are mostly unplanned and non-engineered [5], resulting in many slope failures that can create catastrophic disasters such as landslides. Unplanned human interventions, such as rural road construction, quarrying or poor terrace management can increase 
the fragility of slopes and, consequently, the occurrence of landslides and erosion [6]. Landslides not only destroy lives and livelihood activities, but they also block roads while causing long-term environmental degradation [3,7]. Nepal's hill roads are impacted by landslides mostly triggered by intense rainfall [8]. Roadside slope failures are mostly shallow in nature and frequently occur in the hill side and embankment roads. Deep-seated landslides on the other hand are also common because of naturally occurring geological features in the Himalayas, but these can also be aggravated due to human activities [8].

In 1979, the first inventory of landslides in Nepal was published by Laban [9], who noted that only about five percent of the landslides in Nepal were caused by roads (or human activities). At this time, the road density was very low. Since then, the road density increased to $13.7 \mathrm{~km} / 100 \mathrm{~km}^{2}$ in 1998 to $49.6 \mathrm{~km} / 100 \mathrm{~km}^{2}$ in 2016 [10,11]. According to Petley et al. (2007) [12], the number of landslide fatalities in Nepal increased dramatically between 1978 and 2005, these were partially linked to poorly constructed rural roads [3]. On 29 July 2015, many landslides were triggered due to intense monsoonal rain that killed 29 people in the Central-Western hilly region of Nepal [13], of which nine were killing in the Panchase Region [14]. One of the underlying causal factors of the fatal landslides in the region was non-engineered and unplanned rural roads, triggered by intense rainfall [14]. There is evidence of many other fatal landslides caused by rural roads in the country $[15,16]$. Nonetheless, haphazard rural road constructions continue, which urgently require suitable measures for stabilizing unstable rural road slopes [17]. In Nepal, rural roadside slope failures and related disasters are recognized despite being understudied [3] and often neglected [18,19], while less attention is paid to cost-effective and sustainable roadside slope protection measures. According to World Bank (WB) (2011), more than $50 \%$ of the rural roads are non-operational during the monsoon period and the extended period even after the monsoon is over, leading to huge consequences for communities including reduced access to markets, schools, and health clinics [20].

The use of plant species to stabilize instable roadside slopes has been researched and applied by many researchers and professionals around the globe [21]. The technique which combines vegetation with civil engineering structures, such as gabion walls or drainage canals, for maximizing slope stability is known as soil bioengineering in Nepal [22,23], while terms such as eco-technology, bio-technology, eco-engineering, ecological engineering, etc. are also in use [24-26]. More recently, terms such as ecosystem-based disaster risk reduction (Eco-DRR), ecosystem-based adaptation (EbA), nature-based solutions ( $\mathrm{NbS}$ ), and green infrastructure (GI) all encompass various types of soil bioengineering and ecosystem restoration. Soil bioengineering is now commonplace, particularly in the field of conservation in Europe [27-30], as it is known to be sustainable, environmentally friendly, and cost-effective [31].

This article describes a proposed assessment framework for "eco-safe rural roads" based on the research undertaken in the Panchase Region of Nepal (Figure 1) as part of the "Ecosystems Protecting Infrastructure and Communities" (EPIC) project (2012-2017), implemented by the International Union for Conservation of Nature (IUCN), where three community-led eco-engineering demonstration sites were established alongside the roads. The framework includes the findings obtained at different stages of the research such as intensity of rainfall, slope instability due to the rainfall-induced saturation-depth, and the performance of the plant species (i.e., plant species contribution for soil slope protection) used in the demonstration sites. In addition, the insights, experiences, and local knowledge observed while performing the research in the region were also considered as an example to support the assessment framework. 


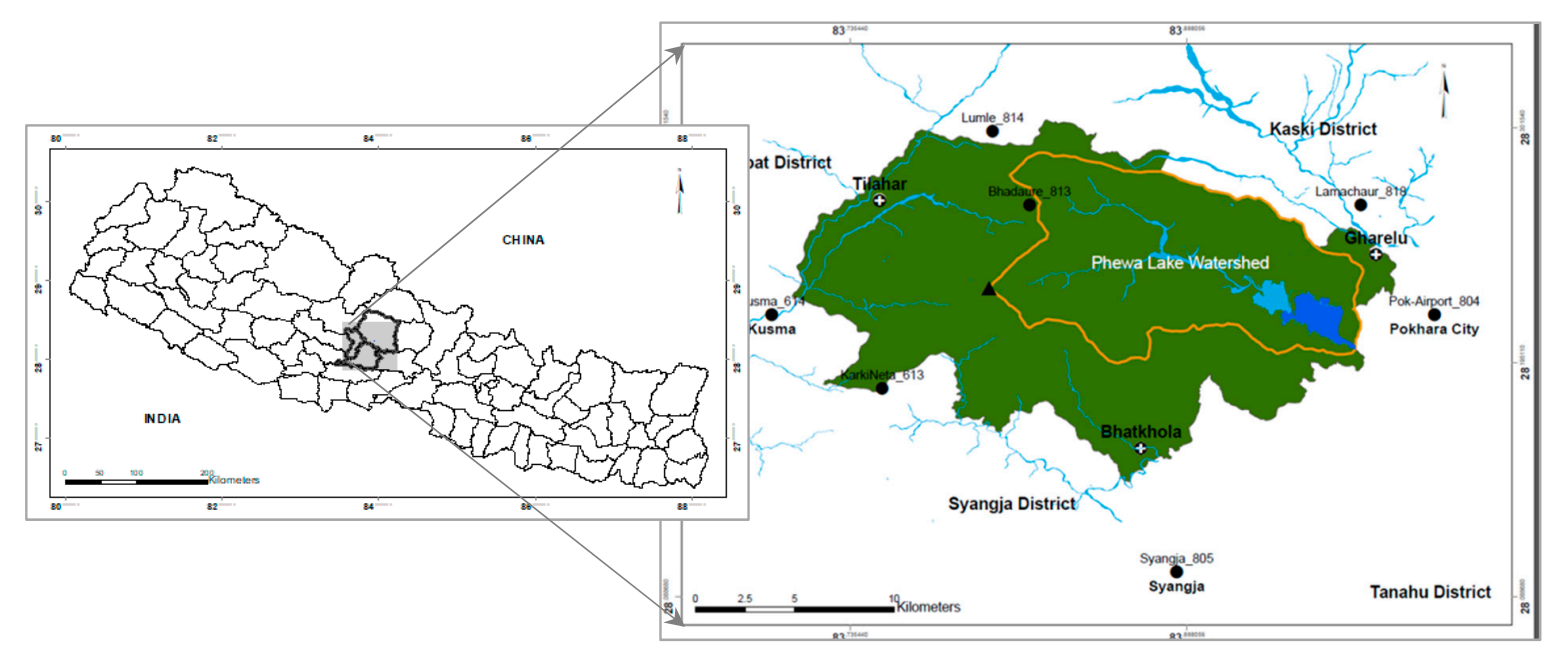

Figure 1. Location of Panchase geographic region in Central-Western hills of Nepal.

\subsection{Eco-Safe Rural Roads-Concept and Definition}

Eco-engineering or soil bioengineering measures encompass the use of vegetation, either alone or in combination with conventional civil engineering structures, for control of soil erosion and shallow landslides [32]. In eco-engineering systems, emphasis is given to the environment (e.g., soil, water, air, flora/fauna, society), as well as inert and live construction materials [31], to stabilize soil slopes, thereby avoiding disruptions. The plant species used in eco-engineering perform an engineering function proven to provide a combination of sustainability benefits such as protection against soil erosion in the short term and long-term stabilization due to the reinforcement effect of the roots on the soil $[21,26]$. There is now sufficient research [31] to demonstrate that eco-engineering measures are robust enough in many situations to constitute an alternative over civil engineering solutions. Often referred to as "hybrid" ecological engineering, soil bioengineering techniques can be combined with civil engineering measures for the most optimal protection, when they do not cause harm to natural systems.

Eco-engineering can readily be applied to stabilizing roadside slopes toward, so called "eco-safe roads" [18]. Faulty roads are also dangerous roads and the purpose of eco-engineering in this context is to ensure both safer rural roads, and more sustainable mitigation of roadside slope failures [18]. The assumption of "eco-safe rural roads" is that the roads should be operational year-round to ensure economic activities at the local level, and to provide better access to the markets, healthcare, and education, thereby increasing the communities' resilience. The "eco-safe road" approaches, provides sustainable and cost-effective solutions with multiple purposes: reducing environmental degradation and improving livelihoods, thereby addressing climate change adaptation (CCA), integrated water resource management (IWRM), disaster risk reduction (DRR), bio-diversity conservation, and public health [29,33-36]. While the eco-engineering is a type of $\mathrm{NbS}[24,37]$, which is gaining attention among scientists, professionals, and policy-makers around the globe used for "eco-safe roads" to mitigate a range of roadside slope failures, in which deep-rooted plant species are used alone or in combination with civil engineering measures.

The European Union (EU) endorses NbS and is investing heavily in research on $\mathrm{NbS}$ through its Horizon 2020 [38] program which focuses on various ecological engineering techniques, performance measures, and policies for sustainable development and DRR [27]. However, according to Nesshover et al. (2017) [39], there is still debate on how to define NbS, with questions on the scope of interventions. A review of the literature reveals two definitions conceptualized and elaborated by the IUCN and the European Commission (EC). IUCN defines NbS as "actions to protect, sustainably manage, and restore natural or modified ecosystems that address societal challenges effectively and adaptively, simultaneously providing human well-being and biodiversity benefits" [40]. The IUCN definition adopted eight foundational principles of endorsement of nature conservation norms, consideration of local natural and cultural 
contexts, fairness and equity in delivering societal benefits, application at the landscape scale, and a forward-looking attitude in considering the evolution of ecosystems and associated benefits, while the EU defines NbS as cost-effective, locally adapted, and resource-efficient solutions that are "inspired by, supported by, or copied from nature" and "simultaneously provide environmental, social, and economic benefits and help build resilience" by bringing "more, and more diverse, nature and natural features and processes into cities, landscapes, and seascapes" [41]. Both definitions of $\mathrm{NbS}$ recognize nature as a common denominator that can play major role in addressing the societal challenges, CCA and DRR, whereas the IUCN definition is stricter in its definition of what constitutes a natural ecosystem. Both definitions characterize $\mathrm{NbS}$ as "an umbrella" concept of other established ecosystem-based approaches [35] such as eco-engineering, ecosystem-based DRR, or ecosystem-based adaptation that encompass cost-effectiveness, adaptability, and application of participatory processes, as well as multi-disciplinary and evidence-based strategy [36].

\subsection{Review of Existing NbS Assessment Frameworks}

Our literature review revealed that the scientific community, academia, and policy-makers have proposed a number of assessment frameworks to enhance the implementation of variety of NbS strategies [36], while Mickovski and Thomson (2017) [31] demonstrated the framework for the sustainability assessment of eco-engineering measures. These frameworks have partially addressed the complexity of various NbS strategies. For instance, the WB guidance, published in 2017 [37] for flood risk management, demonstrated that $\mathrm{NbS}$ strategies are robust to act as alternatives or complementary to the conventional engineering measures [35]. According to Calliari et al. [35], the WB (2017) document describes the timeline and activities needed to implement $\mathrm{NbS}$ and, thus, starts from the assumption that they were identified as the best option. The WB (2017) guidance described the traditional flood risk management cycle and highlighted several factors such as identifying flood hazard(s), the main stakeholders, scale of the natural system, assessing flood risk to the ecosystem and potential DRR, management options, identifying acceptable risks, resources required, benefits and effectiveness of the selected measures, local need and capacity, and, finally, implementation. Many of the factors discussed in WB (2017) guidance were also observed in the framework proposed by Raymond et al. [42], who assessed the co-benefits of $\mathrm{NbS}$ across elements such as (i) socio-cultural and economic systems, (ii) biodiversity, (iii) ecosystems, and (iv) climate and physical environment with a specific focus on urban environment. The WB framework was able to draw attention to the beneficial and adverse impacts of $\mathrm{NbS}$ [35] and presented the following processes [42]:

(i) Identifying the problem to be addressed or opportunity to be taken;

(ii) Selecting and assessing $\mathrm{NbS}$ and related actions;

(iii) Designing NbS implementation processes;

(iv) Implementing NbS;

(v) Frequently engaging stakeholders and communicating co-benefits;

(vi) Transferring and upscaling NbS;

(vii) Monitoring and evaluating the benefits.

Table 1 presents a summary of different NbS assessment frameworks reviewed, highlighting the challenges, proposed NbS strategies, the aim and scale of the framework, and the approach and methods used to prepare the framework. 
Table 1. Summary of key characteristics of nature-based solutions (NbS) assessment frameworks.

\begin{tabular}{|c|c|c|c|c|c|}
\hline Author(s) & Challenges & Scale & Type of $\mathrm{NbS}$ & Aim & Approach and Method \\
\hline EEA [28] & $\begin{array}{c}\text { DRR (CC-related hazards, } \\
\text { landslides) }\end{array}$ & $\mathrm{L}, \mathrm{R}$ & $\begin{array}{c}\text { Intervention of green } \\
\text { infrastructures to mitigate } \\
\text { extreme weather and } \\
\text { climate-related events such as } \\
\text { landslides }\end{array}$ & $\begin{array}{l}\text { To assess the hazard } \\
\text { potential due to extreme } \\
\text { weather and identify GI } \\
\text { elements, pursued at } \\
\text { landscape scale with a } \\
\text { focus on rural } \\
\text { environments }\end{array}$ & $\begin{array}{l}\text { To assess conditions of ecosystem } \\
\text { services, evaluate hazard level } \\
\text { (high, medium, and low) and } \\
\text { prepare hazard map, and design } \\
\text { and implement GI to } \\
\text { mitigate/reduce the impact of } \\
\text { disaster risks }\end{array}$ \\
\hline Raymond et al. [42] & $\begin{array}{c}\text { CCM and CCA, WRM, GI, } \\
\text { PPG, UR }\end{array}$ & $\mathrm{U}$ & $\begin{array}{l}\text { No specific measures assessed, } \\
\text { reference to wider categories of } \\
\text { ecosystem-based approaches, } \\
\text { and green-blue infrastructures } \\
\text { such as ES, ecological } \\
\text { engineering, ecosystem-based } \\
\text { management }\end{array}$ & $\begin{array}{c}\text { To assess the NbS through } \\
\text { economic, environmental, } \\
\text { and social co-benefits and } \\
\text { cost analysis }\end{array}$ & $\begin{array}{l}\text { For each challenge, potential NbS } \\
\text { are identified together with } \\
\text { expected impacts, indicators of } \\
\text { impacts, related metrics, and } \\
\text { assessment methods }\end{array}$ \\
\hline Van Wesenbeek et al. [37] & DRR (flood) & $\mathrm{L}, \mathrm{R}$ & $\begin{array}{l}\text { Interventions implying } \\
\text { managing the present } \\
\text { ecosystem or activity } \\
\text { intervening on/creating new } \\
\text { ecosystem }\end{array}$ & $\begin{array}{l}\text { To provide guidance for } \\
\text { planning, assessing, } \\
\text { designing, implementing, } \\
\text { monitoring, managing, } \\
\text { and evaluating the NbS }\end{array}$ & $\begin{array}{l}\text { Flood risk management project } \\
\text { cycle }\end{array}$ \\
\hline $\begin{array}{l}\text { Mickovski and Thomson } \\
\text { [31] }\end{array}$ & $\begin{array}{l}\text { Sustainability assessment } \\
\text { of eco-engineering }\end{array}$ & $\mathrm{L}, \mathrm{R}$ & $\begin{array}{l}\text { To assess the sustainability of } \\
\text { eco-engineering measures }\end{array}$ & $\begin{array}{l}\text { To develop a framework } \\
\text { for the sustainability } \\
\text { assessment of } \\
\text { eco-engineering measures }\end{array}$ & $\begin{array}{c}\text { Bench marking of key } \\
\text { performances indicators (KPIs) } \\
\text { through sustainable assessment } \\
\text { method (SAM) }\end{array}$ \\
\hline Calliari et al. [35] & DRR (CC-related hazards) & $\mathrm{L}, \mathrm{R}$ & $\begin{array}{l}\text { No specific measures assessed, } \\
\text { regulation and maintenance, } \\
\text { provisioning and cultural } \\
\text { services }\end{array}$ & $\begin{array}{l}\text { To assess direct } \\
\text { benefits/costs and } \\
\text { co-benefits/costs }\end{array}$ & $\begin{array}{c}\text { To assess baseline, backcasting, and } \\
\text { setting the criteria to evaluate } \\
\text { alternatives }\end{array}$ \\
\hline
\end{tabular}

Acronyms: $\mathrm{CCM}=$ climate change mitigation, $\mathrm{CCA}=$ climate change adaptation, $\mathrm{DRR}=$ disaster risk reduction, $\mathrm{CC}=$ climate change, $\mathrm{ES}=$ ecosystem services, $\mathrm{WRM}=$ water resource

management, $\mathrm{GI}=$ green infrastructure, $\mathrm{PPG}=$ participatory planning and governance, $\mathrm{UR}=$ urban regeneration, $\mathrm{L}=$ local, $\mathrm{R}=\mathrm{regional}, \mathrm{U}=\mathrm{urban}$. 


\section{Materials and Methods}

\subsection{Research Strategy}

In order to establish the assessment framework specific to the use of eco-engineering for safer rural roads, or "eco-safe roads" in the Panchase Region of Nepal, the research followed a pragmatic approach combining published research and existing best practices. Review of published articles and consultation with the concerned stakeholders, such as community people, professionals working in the rural road sector, policy-makers, and researchers, was contextualized through workshops, scoping visits, focused group discussions (FGDs), key informant interviews (KII), and case studies. Nine semi-structured interviews with a range of stakeholders such as local authorities, engineers, conservation professionals, local non-governmental organizations (NGOs), and members of the community adjacent to the landslide susceptible roadsides were conducted in 2013 and 2014 in the Panchase area of Central-Western Nepal. The FGDs and interviews were recorded, and main themes and key words were analyzed in order to establish key principles for the development of an assessment framework for establishing "eco-safe roads".

The scoping visits (15-17 November 2013 and 10-14 April 2014) followed by the inception workshop provided useful information for identifying key issues related to landslides in the Panchase Region. These included the fact that the region is highly susceptible to slope failure, not only due to the fragile landscape but also due to highly intense human activities, such as unplanned rural road construction. In conjunction with the scoping visits, the inception workshop identified three roadside locations for establishing eco-engineering demonstration sites and locations for the rhizotrons (Gharelu in Kaski, Bhatkhola in Syangja, and Tilahar in Parbat Districts). Rhizotron is a root-monitoring device [43] established near vertical $\left(\sim 85^{\circ}\right)$ excavated roadside slopes. The vertical part of the slope was fixed with transparent plexiglass and protected by three removable layers of insulating materials. On the upper slope of the rhizotron, plant species were planted systematically dividing the rhizotron length in equal divisions. The research was focused on perennial grass species, as grasses can be established quickly, spread faster to give good ground cover, and contain a high degree of tolerance [44]. The FGD identified seven local grass species: (1) Amriso (Thysanalana maxima), (2) Urlo-Khar (Cymbopogon microtheca), (3) Napier (Penniseluim purpurreum), (4) Salim-Khar (Chirysopogon gryllus), (5) Kans (Saccharum spontaneum), (6) Kush (Cannabis indica), and (7) Babiyo (Eulalioipsis binate). Although not being a local species, Vetiver (Chrysopogon zizanioides) grass was also chosen as this species has well-known strong and deep root systems [45]. Plantations took place during the early pre-monsoon (April 2014) to allow the seedlings to develop roots and survive during the intense monsoon rainfall. Plantations before the monsoon require careful action to maximize the plant survival [46].

Various parameters such as species survivorship, canopy coverage, root-shoot (dry) biomass, root diameter, and depth (shallow $<30 \mathrm{~cm}$ and deep $\geq 80 \mathrm{~cm}$ ), followed by root contribution in soil cohesion, were evaluated according to Wu et al. (1979) [47], while root mapping was performed as demonstrated by Bohm (1979) [48]. These parameters were considered to be the key performance indicators (KPIs) of the plant species used. To quantify the KPIs of the species, well-established principles and norms such as those of Bohm (1979) [48] and Pohl et al. (2011) [49] were adopted. The KPIs were fitted into a principal component analysis (PCA) model to better understand the species quality for the eco-engineering measures. PCA is a statistical procedure that uses an orthogonal transformation of a set of observations and explores the possible correlation among the linearly uncorrelated variables [50].

The inventories of rural roads and landslides in the Phewa Lake watershed were prepared firstly from the remote sensing (RS) images and secondly verified through the field survey. To better understand the slope stability and underlying causes, the research was designed to implement a physically based infinite slope stability model according to Chae et al. (2015) [51]. For this purpose, a subset of the Panchase mountain region, the Phewa Lake watershed $\left(\sim 111.5 \mathrm{~km}^{2}\right)$ was modeled utilizing the soil properties, topographical variables derived from the 12.5-m-resolution digital elevation 
model (DEM), and rainfall intensity, allowing a landslide susceptibility model (LSM) to be established. The LSM was verified adopting a receiver operating characteristics (ROC) curve $[52,53]$ utilizing the inventory maps. The research followed a pragmatic approach based on a regional rainfall intensity-duration-frequency (IDF) model, published by Devkota et al. (2018) [54], and the soil depth to bed rock (SDTB) [55] of the Phewa Lake watershed. The saturation depth of the soil profile at watershed scale was estimated adopting the Green-Ampt (GA) model according to Dingman (2002) [56], while soil physical and hydrological properties were derived either in the field or in the laboratory. The initial moisture content of the soil in the watershed was considered to be $80 \%$ due to the antecedent rainwater.

As part of the capacity development, a two-day-long community-based soil bioengineering training was conducted for the road users adjacent to the demonstration sites. The community participation in the training was gender-balanced with nearly equal participation of male and female members. During the training, a dialogue was established with community representatives to discuss the objectives of the demonstration sites and the research. A local road user's group (RUG) was formed for each demonstration site, while the RUGs adjacent to the road were given the role of determining which areas to rehabilitate, which area to select for the rhizotron, and which plant (grass) species to select. They were also responsible for the seedling collection, plantation, and routine maintenance and weeding. Both community and engineering knowledge was used to design eco-engineering measures and quality control of the construction activities adopted from Devkota et al. (2014) [57], Howell (1999a) [58], Howell (1999b) [59], and Gray and Sotri (1996) [21] where applicable. Community people were also engaged and compensated for other construction activities such as roadside drainage, stone wall construction, and stone rip-rap surface drainage, while local government officials and technical experts were assigned to design and co-monitor the work quality and progress with the community leaders.

In order to address the sustainability of the eco-engineering measures implemented at the demonstration sites, this research attempted to establish a knowledge transfer partnership (KTP) as suggested by Raymond et al. [42] among the key stakeholders such as researchers, academics, local government representatives, and local people. The integration of local knowledge and physical science adopted in the research established the foundation and the conceptualization for the proposed assessment framework. The case studies provided data and experiences for establishing and testing the eco-engineering concept, as well as its complexities and challenges.

\subsection{Case Study}

\subsubsection{Baseline}

The Gharelu site $\left(28.24397^{\circ}\right.$ north $(\mathrm{N}), 83.9735^{\circ}$ east (E), $1120 \mathrm{~m}$ above sea level (masl)) was located about a 15-min drive from the city of Pokhara in Kaski District on the way to Sarangkot, a popular tourist destination. A nearly 1-km-long earthen road connecting the village Gharelu to the main road to Sarangkot was built by the community at their own cost in 2011-2012. However, the road is not functional due to frequent shallow failures during monsoon season.

The chosen site in Syangja was in Bhatkhola $\left(28.156^{\circ} \mathrm{N}, 83.86708^{\circ} \mathrm{E}, \sim 1020\right.$ masl), located about a 5-min drive (15-min walk) from the nearest all-weather road at Phedikhola, on the way to Syangja district headquarter from Pokhara. The earthen road from Phedikhola to Bhangshing of Syangja District was open in support of the government in 2007-2008. During monsoon season, the road section at Bhaktkhola blocked traffic movement to the northern part of the district, where monsoonal rainwater action created deep gullies and significant erosion from the roadside spoils. The location was degraded, and the gullies were unmaintained.

The case of the Tilahar site $\left(28.26886^{\circ} \mathrm{N}, 83.74881^{\circ} \mathrm{E}, \sim 1060\right.$ masl $)$ was the worst in terms of soil fragility compared to the other two sites, located $2 \mathrm{~km}$ east of the all-weather road at Dimuwa on the way to Kusma, the district headquarters of Partbat District. The road was constructed by the local 
government in 2010-2011, but the road is unmaintained. Every monsoon, a large amount of debris, together with boulders, rolls down from the unmaintained road to the school located below the road.

\subsubsection{Objectives}

The objectives of the research were to (1) assess slope stability, and the causal and trigging factors of landslides in this area, (2) evaluate the KPIs of the selected plant species (grass) for the eco-engineering measures through the community-based rural roadside eco-engineering demonstration sites, and (3) establish dialogue on the use of local and scientific knowledge for establishing eco-safe rural roads with the community people, professionals, researchers, media representatives and policy-makers.

\subsubsection{Selection, Design, and Implementation of NbS Techniques}

The $\mathrm{NbS}$ technique implemented in this research was a hybrid type of eco-engineering, encompassing simple civil engineering structures and the plantation of perennial grass species. Civil structural measures such as roadside and surface drainage were designed considering rainfall intensity [54], while civil and geo-technical engineering approaches were adopted for the toe and retaining wall construction. Plantation designs followed Howell (1999b) [59] in diagonal rows, and clusters were maintained for each species. Among the three sites, Bhatkhola represented the largest site, with about $2200 \mathrm{~m}^{2}$ of area, followed by Tilahar $\left(\sim 2000 \mathrm{~m}^{2}\right)$ and Gharelu $\left(\sim 1500 \mathrm{~m}^{2}\right)$. However, the actual plantation area represented $156 \mathrm{~m}^{2}, 620 \mathrm{~m}^{2}$, and $1210 \mathrm{~m}^{2}$, respectively, at the Bhatkhola, Tilahar, and Gharelu sites. The reason for the smaller plantation area in Bhatkhola was that the site required gully protection, requiring fewer seedlings. In addition, the number of seedlings varied according to the slope length and orientation. In some case, species such as Amriso (T. maxima) were planted at horizontal spacing about 30-50 cm apart, whereas others were planted at 10-20-cm spacing [60]. The vertical spacing is generally governed by the landscape slope and soil type. In this study, the vertical rows were maintained at $100 \mathrm{~cm}$. Where gully protection was needed, Amriso (T. maxima) was planted at $100 \mathrm{~cm}$ and $30 \mathrm{~cm}$ apart, respectively, in vertical and horizontal directions, with additional reinforcing poles in between acting as a live palisade [59].

Among the eight different grass species chosen, four species, (1) Amriso (T. maxima), (2) Urlo-Khar (C. microtheca), (3) Napier (P. purpurreum), and (4) Salim-Khar (C. gryllus), were planted in the designated demonstration sites (Table 2), whereas all eight species were used for the rhizotron monitoring. On the upper slope of the rhizotron (Figure 2), the selected species saplings (Amriso (T. maxima), Urlo-Khar (C. microtheca), Napier (P. purpurreum), Salim-Khar (C. gryllus), Kans (S. spontaneum), Kush (C. indica), Babiyo (E. binate), and Vetiver (C. zizanioides)) were planted $20 \mathrm{~cm}$ (plant to plant) apart in the horizontal direction and $100 \mathrm{~cm}$ apart in the vertical direction (row to row), except Amriso (T. maxima), for which plant separation was $30 \mathrm{~cm}$ and $100 \mathrm{~cm}$, respectively. The rhizotron in Gharelu was $8 \mathrm{~m}$ long, while this was $6 \mathrm{~m}$ long for other sites established in the months of December 2014. Altogether, in Gharelu, the plants were planted in five rows (No. of saplings $=7 \times 25+1 \times 20$ ), whereas, in Tilahar and Bhatkhola, there were four rows (No. of saplings $=7 \times 20+1 \times 16$ ). 
Table 2. Number of seedlings planted in each demonstration site monitored by the community members.

\begin{tabular}{ccccc}
\hline $\begin{array}{c}\text { Demonstration } \\
\text { Site/Local Species } \\
\text { Name }\end{array}$ & Species Name & $\begin{array}{c}\text { Plantation } \\
\left.\text { Area } \mathbf{( m}^{\mathbf{2}}\right)\end{array}$ & $\begin{array}{c}\text { Number of } \\
\text { Saplings }\end{array}$ & $\begin{array}{c}\text { Spacing, } \\
\text { Horizontal:Vertical } \\
\text { (cm) }\end{array}$ \\
\hline Gharelu & & 1210 & & $10: 100$ \\
\hline Urlo-Khar & Cymbopogon microtheca & 450 & 3000 & $10: 100$ \\
Nepiyar & Penniseluim purpurreum & 300 & 2000 & $10: 100$ \\
Salim-Khar & Chirysopogon gryllus & 200 & 1050 & $30: 100$ \\
Amriso & Thysanalana maxima & 260 & & $10: 100$ \\
\hline Tilahar & & $\sim 620$ & 1200 & $10: 100$ \\
\hline Urlo-Khar & C. microtheca & 120 & 500 & $30: 100$ \\
Nepiyar & P. purpurreum & 50 & 750 & 1000 \\
Salim-Khar & C. gryllus & 75 & 1500 & $10: 100$ \\
Amriso & T. maxima & 375 & & $10: 100$ \\
\hline Bhatkhola/Saunepani & & $\sim 156$ & 250 & $30: 100$ \\
\hline Urlo-Khar & C. microtheca & 25 & 180 & \\
Nepiyar & P. purpurreum & 18 & 390 & \\
Salim-Khar & C. gryllus & 15 & & \\
Amriso & T. maxima & 98 & & \\
\hline
\end{tabular}
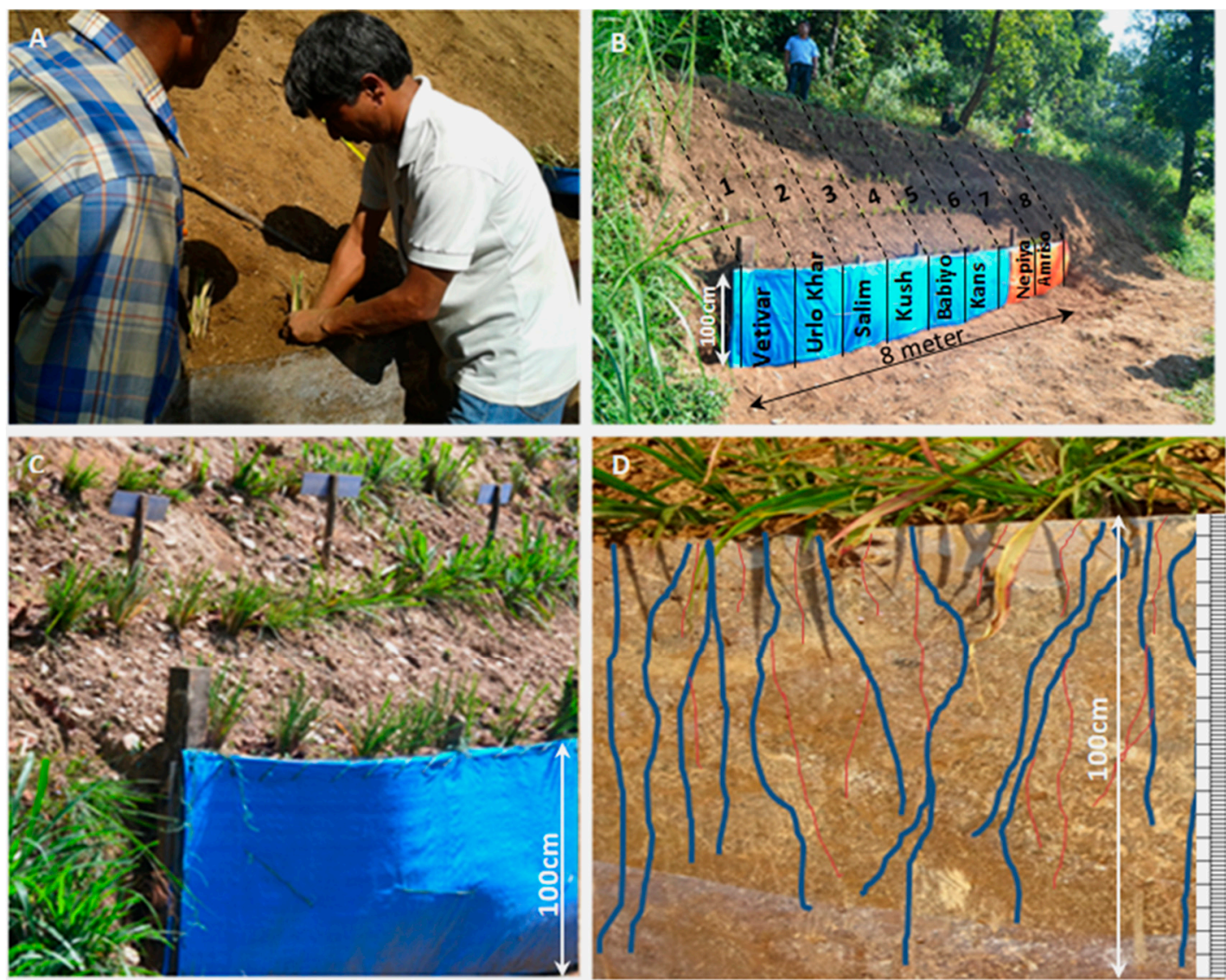

Figure 2. Example of rhizotron established in Gharelu demonstration site in Kaski (established in November 2014) marked on a field: (A) during the plantation; (B) just after completion; (C) after three months of the establishment; (D) tracing of roots. The red line denotes roots of Vetiver grass (Chrysopogon zizanioides) after six months (April 2015), and the blue line denotes old roots of the same species as seen from the rhizotron window after 12 months (November 2015). 


\subsubsection{Monitoring and Evaluation}

Community representatives maintained records of the seedling survival rates, growth trends, and other routine maintenance of the demonstration sites. The root growth was monitored through the rhizotron windows, as shown in Figure 2D, by the technical staff.

After 18 months of establishment of the rhizotrons, the canopy cover of the planted species was visually estimated using expert knowledge, while the first row of plants on the rhizotron was carefully excavated so as to deliver a sample to the laboratory for root-shoot biomass (dry) estimation. During the excavation, the roots were sampled at different depths $(0-10,10-30,30-50,50-80$, and 80-100 cm), the diameter was measured, and tensile strength tests were performed. The root mapping was performed dividing the roots in four classes $(0-0.5 \mathrm{~mm}, 0.5-1 \mathrm{~mm}, 1-2 \mathrm{~mm}$, and $>2 \mathrm{~mm})$ on the excavated (vertical) cut slope of the three rhizotrons. The roots were counted on a regular grid $(10 \mathrm{~cm}$ $\times 10 \mathrm{~cm}$ ), and the root area ratio (RAR) was estimated at different depths, followed by the rooting depth and diameter. Finally, the species root contribution in soil cohesion was estimated.

The case studies demonstrated that roadside slope failure and soil erosion in the three demonstration sites were successfully mitigated through the adopted eco-engineering techniques (Figure 3), which indicated the effectiveness of the plant species, combined with simple civil engineering measures.
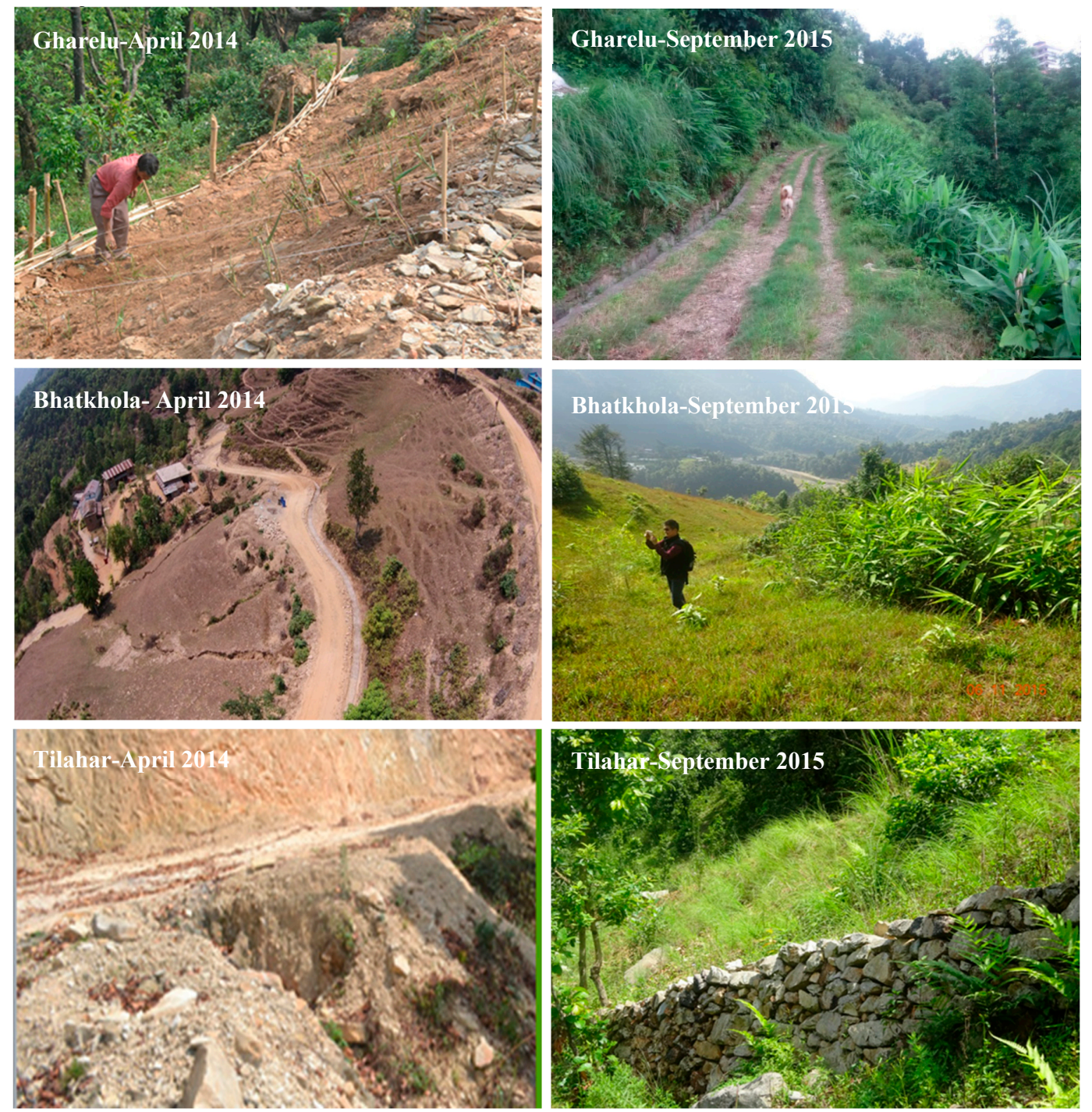

Figure 3. View of the demonstration sites before and after 18 months of establishment. 


\section{Results and Discussion}

\subsection{Rural Road and Landslides in Phewa Watershed of Panchase Region}

Analysis of RS images and field mapping revealed that the total length of the rural roads in the watershed was about $305 \mathrm{~km}$ through the end of August 2016, with a road density of about $2.74 \mathrm{~km} / \mathrm{km}^{2}$. Unplanned and non-engineered construction of rural roads is one of the major causes of soil loss [12,61] in the region. There were 373 field-validated slope failure events during the period of 2013 to 2016 , of which 199 events were caused by the roads, while the triggering factor was rain. The smallest and largest units of mapped landslides were $\sim 19 \mathrm{~m}^{2}$ and $\sim 0.24 \mathrm{~km}^{2}$, respectively. Figure 4 presents the landslides (Department of Mines and Geology (DMG) 2002 and 2013-2016) and the rural roads until the end of August 2016 in the Phewa Lake watershed. As per Vuillez et al. (2018) [62], the older landslides were observed mostly on natural slopes (e.g., forests and cultivated terraces), whereas most of the recent failures were along the roads.

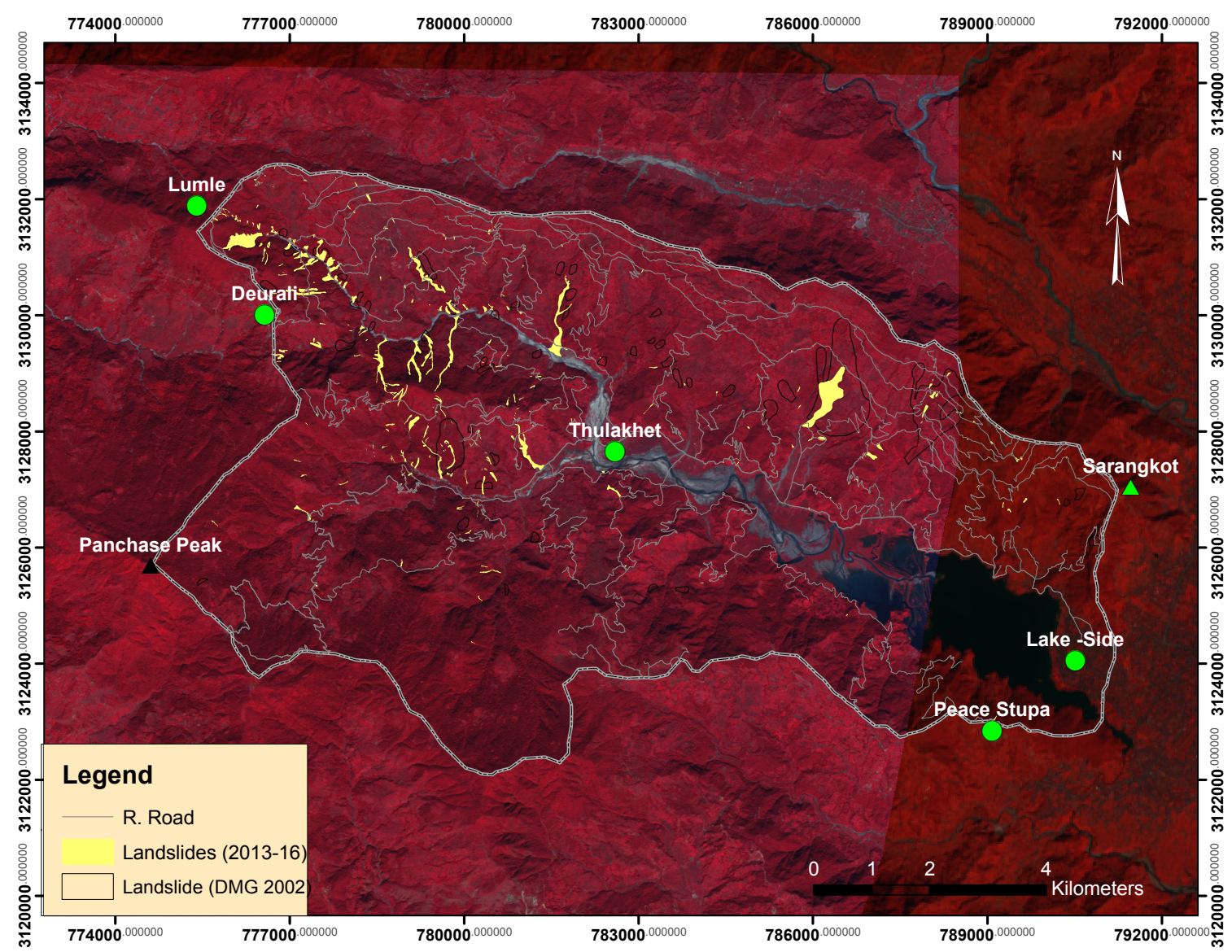

Figure 4. Inventory map (combined) of rural roads, landslides (2013-2016), and DMG 2002 [63], in a background false-color composite RapidEye image $(5 \mathrm{~m} \times 5 \mathrm{~m})$ taken on 5 October 2015 [55].

An infinite slope stability model was implemented under two different rainfall intensity scenarios (scenario 1: $4.65 \mathrm{~cm} / \mathrm{h}, 100$-year return period; scenario 2: $5.70 \mathrm{~cm} / \mathrm{h}, 500$-year return period). The model results indicated that $4.84 \%$ and $7.26 \%$ of the watershed area was susceptible to failure (factor of safety (FS) $<1$ ), while $20.10 \%$ and $22.55 \%$ of the area was depicted to be critical (FS = 1-1.5), respectively, for scenarios 1 and 2. The ROC depicted that scenario 1 (Figure 5) was better because of its higher area under the curve (AUC) compared to scenario 2 (scenario 1: AUC =76.4\%; scenario 2: AUC $=71.5 \%$ ). Despite the model result, the LSM also indicated that the majority of rural roads in the watershed 
were either passing through the landslides or in landslide-susceptible areas, for which eco-engineering measures offer the most cost-effective and sustainable solutions.

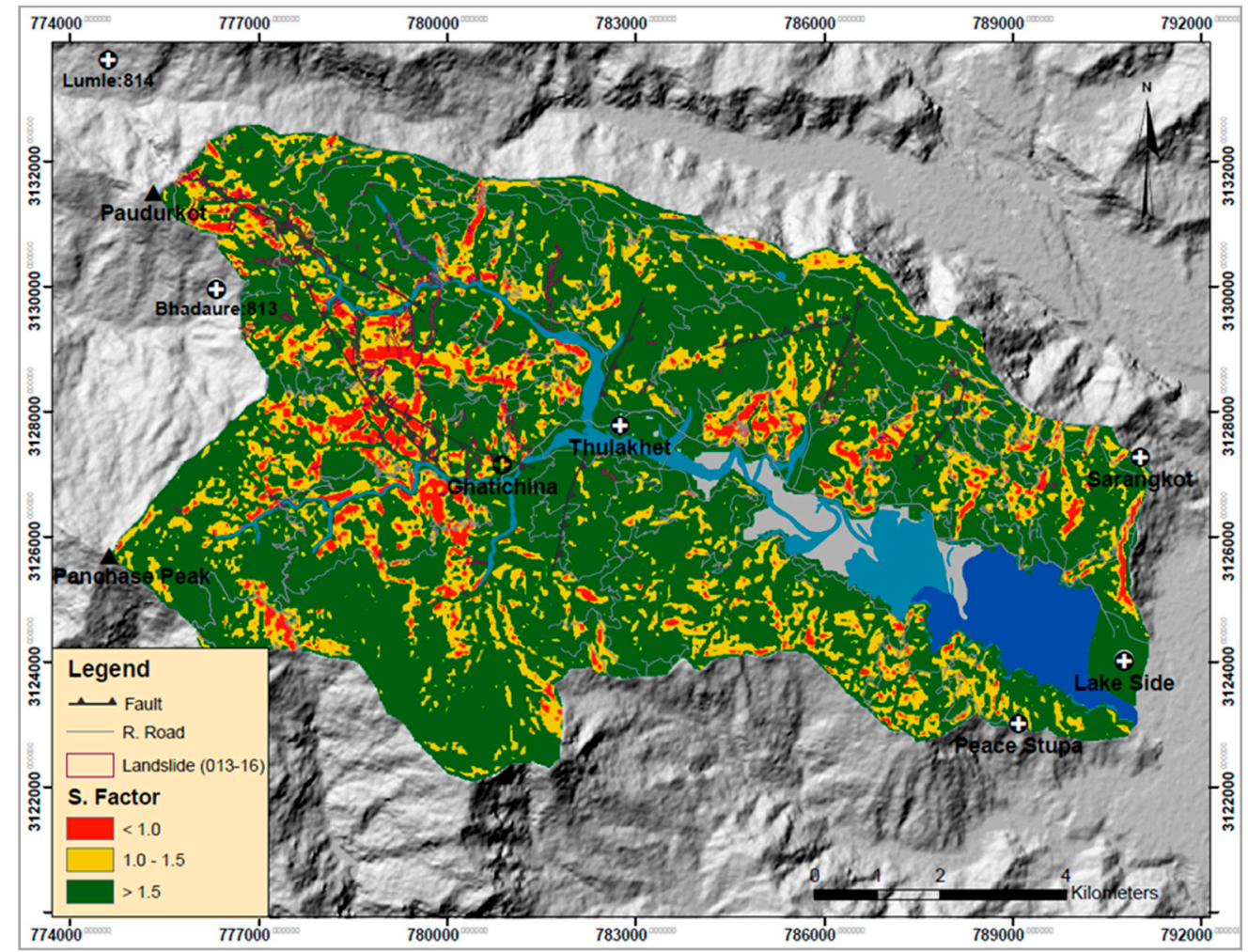

Figure 5. Landslide susceptibility model (LSM) of Phewa Lake watershed (scenario 1) indicting the rural roads, fault line, and landslide inventory of 2013-2016.

\subsection{KPI of the Plant Species}

The perennial grass species that were recommended by the community were also recommended by Devkota et al. (2006) [64] and Howell (1999a) [58], implying that species selection through local knowledge is useful. Altogether, nine indicators were quantified to evaluate the performance of the eight model plant species (Table 3). Among the model species, Babiyo (P. purpurreum) and Kans (D. bipinnata) demonstrated the highest and lowest survival rates of $81.33 \%$ and $65.33 \%$, respectively, and the same observation was valid for the canopy cover. Vetiver (C. zizanioides) followed by Babiyo (P. purpurreum) demonstrated the highest shoot and root dry biomass among all species. This research concluded that the model plant species can be divided into three classes as per the root depth: (1) deep, (2) moderately deep, and (3) shallow, according to which Vetiver (C. zizanioides) and Amriso (T. maxima) were the most deep-rooted species, followed by Urlo-Khar (C. microtheca) and Salim-Khar (E. binata) as moderately deep-rooted $(\leq 50 \mathrm{~cm})$, whilst Babiyo (P. purpurreum), Nepiyar (C. gryllus), Kans (D. bipinnata), and Kush (S. spontaneum) were shallow-rooted species $(\leq 30 \mathrm{~cm})$. The measurement depicted that the root density is higher in the depth range of $0-10 \mathrm{~cm}$ followed by $10-30 \mathrm{~cm}$. As the rooting depth increased, the root density decreased. For the entire mapping, the largest root $(2.07 \mathrm{~mm})$ measured in the rhizotron profile was from Amriso (T. maxima) at the depth range of $0-10 \mathrm{~cm}$. The root tensile strength is one of the more important indicators contributing to increasing the soil cohesion, known as root cohesion. Vetiver (C. zizanioides) demonstrated the highest tensile strength $\left(T_{r}\right)$ from its root cohesion $\left(c_{r}\right)$, followed by Amriso (T. maxima). Table 3 presents a summary of all nine KPIs of the model plant species.

A PCA model was developed utilizing the nine KPIs of the model species to test the quality of plants for eco-engineering measures. The model demonstrated that the performance of Amriso (T. maxima) was better for a soil depth of about $80 \mathrm{~cm}$ among the seven local species, whilst Vetiver 
(C. zizanioides) was the best among all for a soil depth of $100 \mathrm{~cm}$. Urlo-Khar (C. microtheca) and Salim-Khar (E. binata) are useful for landscapes where the soil depth is below $50 \mathrm{~cm}$. Other species were observed to perform well when the landscape soil depth is lower than $30 \mathrm{~cm}$.

Table 3. Summary of KPIs of the model plant (grass) species (mean values from the three sites).

\begin{tabular}{|c|c|c|c|c|c|c|c|c|c|c|}
\hline $\begin{array}{c}\text { Species } \\
\text { Local } \\
\text { Name }\end{array}$ & $\begin{array}{l}\text { Species } \\
\text { Name }\end{array}$ & $\begin{array}{c}\text { Survival } \\
(\%)\end{array}$ & $\begin{array}{c}\text { Canopy } \\
\text { Cover } \\
(\%)\end{array}$ & $\begin{array}{l}\text { Biom-s-Dry } \\
\text { (kg) }\end{array}$ & $\begin{array}{c}\text { Biom-r-Dry } \\
\text { (kg) }\end{array}$ & RAR-Deep & RAR-Shallow & $\begin{array}{c}\text { Rooting } \\
\text { Depth } \\
(\mathrm{cm})\end{array}$ & $\begin{array}{c}T_{r} \\
\text { (MPa) }\end{array}$ & $\begin{array}{c}c_{r} \\
(\mathbf{k P a})\end{array}$ \\
\hline Vetiver & C. zizanioides & 80.00 & 70.57 & 0.83 & 0.32 & 0.0018 & 0.0241 & 0-100 & 45.4 & 14.08 \\
\hline Urlo-Khar & C. microtheca & 78.67 & 48.33 & 0.63 & 0.33 & 0.0018 & 0.0092 & $0-50$ & 24.11 & 7.48 \\
\hline Babiyo & P. purpurreum & 81.33 & 86.67 & 0.78 & 0.54 & 0.0001 & 0.0128 & $0-30$ & 18.25 & 5.66 \\
\hline Nepiyar & C. gryllus & 76.00 & 60.27 & 0.39 & 0.28 & 0.0004 & 0.0082 & $0-30$ & 25.28 & 7.84 \\
\hline Salim-Khar & E. binata & 66.67 & 51.43 & 0.18 & 0.19 & 0.0003 & 0.0104 & $0-50$ & 23.1 & 7.17 \\
\hline Kans & D. bipinnata & 65.33 & 29.70 & 0.26 & 0.19 & 0.0006 & 0.0119 & $0-30$ & 20.24 & 6.28 \\
\hline Kush & S. spontaneum & 72.00 & 41.10 & 0.33 & 0.15 & 0.0010 & 0.0084 & $0-30$ & 21.53 & 6.68 \\
\hline Amriso & T. maxima & 70.67 & 78.63 & 0.62 & 0.30 & 0.0099 & 0.0657 & $0-80$ & 26.65 & 8.27 \\
\hline
\end{tabular}

Biom-s-dry $=$ dry biomass of shoot, Biom-r-dry $=$ dry biomass of root, RAR-deep $=$ root area ratio of deep roots, RAR-shallow $=$ root area ratio of shallow roots, $T_{r}=$ tensile strength, $c_{r}=$ root cohesion .

\subsection{Proposed Eco-Safe Rural Road Assessment Framework}

Based on the case study and review of the available research materials, the "eco-safe rural road assessment framework" was contextualized. The framework outlines the issues to be addressed through appropriate techniques with the pre-defined objectives, and provides guidance for understanding, designing, developing, implementing and assessing eco-engineering as one type of $\mathrm{NbS}$ for the roadside slope protection measures. The proposed framework consists of seven steps. All the steps (shown below) need to be implemented together with the relevant stakeholders, ensuring full gender-balanced community participation from the very beginning through to the final monitoring and evaluation.

1. Define the problems to be addressed (baseline);

2. Establish the eco-safe road objectives;

3. Identify suitable NbS measures and alternatives for eco-safe rural roads;

4. Implement the eco-safe rural road plan;

5. Establish an awareness and communication plan;

6. Mobilize the community for implementation and upscaling;

7. Establish monitoring and evaluation plan and follow-up.

The framework also discussed a number of issues to be addressed at different stages of the eco-engineering implementation process in the Panchase region, which may be suitable for other similar geographical areas of Nepal.

Step 1: Define the Problems to be Addressed (Baseline)

The problems to be addressed by NbS are multi-dimensional and complex; however, participatory and solution-led assessments can support a holistic mapping of the problem and explore the possible feedback loops [42]. Having identified the problem areas, criteria need to be established for assessing the relationships between the problem dimensions and the potential opportunities.

The starting point for a better assessment of "eco-safe rural roads" adopting eco-engineering involves using the $\mathrm{NbS}$ technique to describe and analyze the unsatisfactory situations all along the rural roads to be addressed. This step implies establishing the boundaries and structure of the system of interest, by accurately describing the present situation of climate, socio-economy, ecology, governance, and geographical scale [35]. The aim at this stage is to define the issue of roadside slope failures (i.e., problems in the ground), conceptualize the societal challenges, and create a baseline for the implementation of the "eco-safe rural road" strategy. In order to address and understand the slope failure problems and to establish the baseline of roads in Panchase geographic region, secondary data such as DEM and RS data and other soil physical and climate variables are important. It is important to 
include climate variables, especially the intense rainfall and soil properties of the study area to model and visualize unstable slopes in preparing the baseline. A list of important data and variables to be assessed while defining the problem is shown below.

- Identify and evaluate available (digital) data (e.g., DEM, RS images);

- Assess rural road alignment:

- Map the unstable and shallow landslides failure;

- Assess the drainage patterns;

- Identify and evaluate the soil physical properties and soil depth to bed rock;

- Evaluate the rainfall intensity through the regional IDF model and assess the soil moisture considering the antecedent rainfall and rainy days;

- Implement the infinite-slope stability model considering the rainfall-induced saturation depth to better understand the most unstable locations and the road alignment passing through.

For example, the Panchase region is known to be the zone with the highest rainfall in the country [54]. Studies showed that the rainfall intensity in the region increased due to the climate change impacts [65]. The increased rainfall intensity is the triggering factor for many shallow landslides. In addition to the rainfall, anthropogenic activities such as construction of unplanned rural roads magnified the catastrophic landslides in the region [62].

Figure 6 shows that the representative shallow slope failure, turning into debris flows, damaged the rural road and agricultural lands, and threatened livelihoods in the hilly terrain of Nepal.
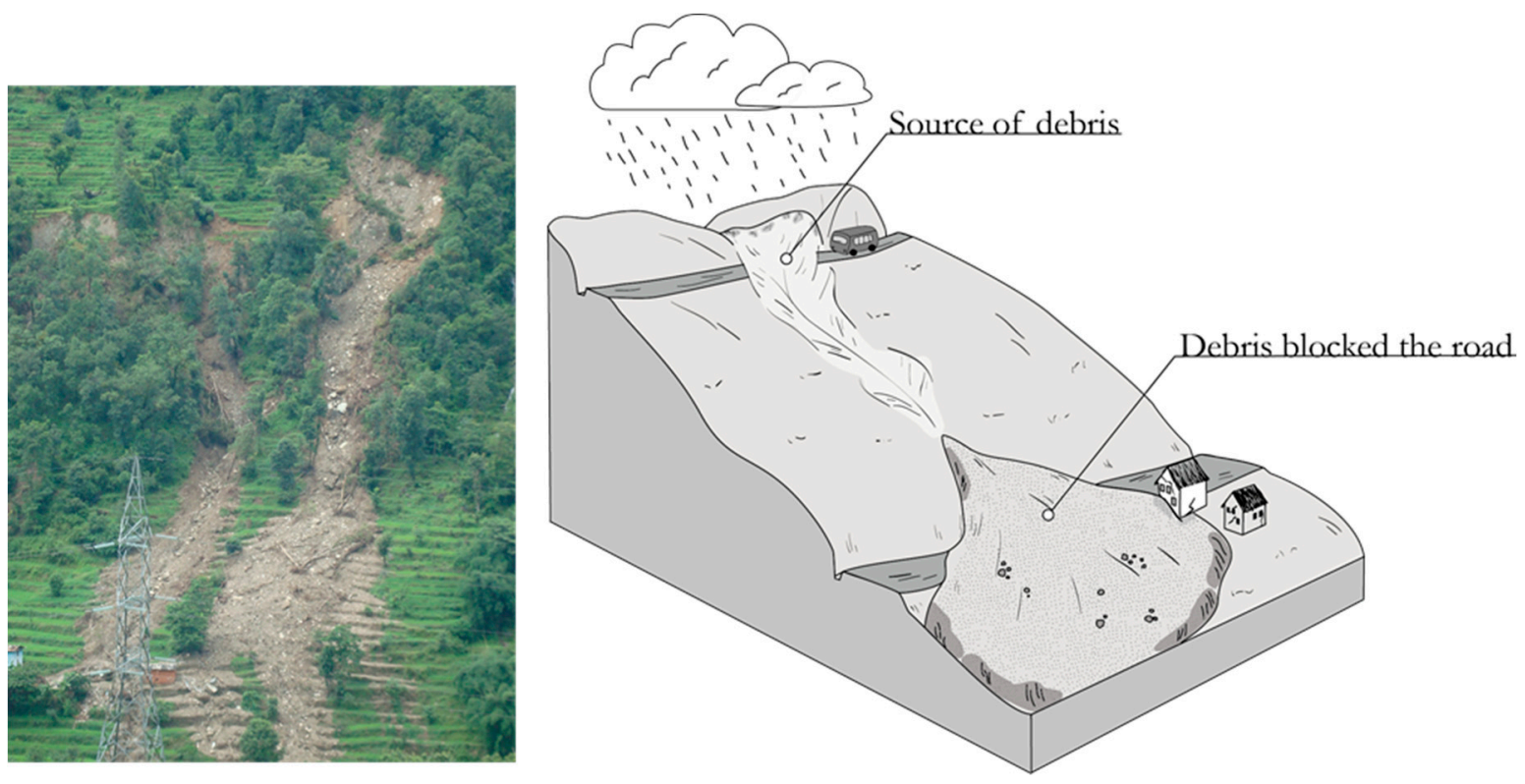

Figure 6. (Left) View of slope failure due to intense rainfall; (Right) schematic illustration of debris flow [57].

Step 2: Establish the Eco-safe Rural Road Objective(s)

The objectives describe the desired situation and, therefore, the concrete goals that an action or set of actions aims to attain [35]. However, the solution put in place to solve or reduce the problem could positively or negatively affect other system components [35]. Calliari et al. (2019) [35] suggested identifying a number of sub-objectives, such as mitigating roadside slope failures, while concurrently providing economic opportunities.

The main objective to be established is to detect solutions for the above-identified problems of rural roadside slope failure through various types of eco-engineering techniques (Figure 7). In addition, 
it is important to consider any possible negative impacts that the eco-engineering solution may have, especially if it is located in a sensitive area along a rural road passing through cultivated land, settlement, and natural forest. Moreover, additional benefits also need to be considered, such as economic benefits from the use of certain species such as Amriso (T. maxima) which communities can harvest and sell on the market. This was the case in Gharelu village, where community members earned up to 500 dollars over three years, which enabled them to expand the bioengineering works there.

\begin{tabular}{|c|c|c|c|c|}
\hline \multicolumn{5}{|c|}{ Main Objective - Mitigation of Rural Road Side Slope Failure } \\
\hline \multirow{4}{*}{ 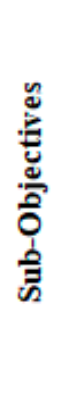 } & $\begin{array}{c}\text { Regulation \& Maintenance } \\
\text { Services }\end{array}$ & $\begin{array}{l}\text { Provisioning } \\
\text { Services }\end{array}$ & Cultural Services & \\
\hline & $\begin{array}{l}\text { Reduction in transportation } \\
\text { cost }\end{array}$ & $\begin{array}{l}\text { Increase local } \\
\text { economic activities }\end{array}$ & Increase Eco-tourism & Economic \\
\hline & Population safety & Increase cooperatives & $\begin{array}{l}\text { Social Inclusion } \\
\end{array}$ & Social \\
\hline & $\begin{array}{l}\text { Reduction of surface erosion } \\
\text { \& sedimentaiton }\end{array}$ & $\begin{array}{l}\text { Flora \& Wildlife } \\
\text { presence }\end{array}$ & $\begin{array}{l}\text { Increase aesthetic } \\
\text { value of the area }\end{array}$ & Environmental \\
\hline
\end{tabular}

Figure 7. Example of main objective and associated sub-objectives of eco-engineering to be implemented along a rural road passing through cultivated land, settlement, and natural forest (modified from Calliari et al. (2019) [35]).

Step 3: Identify suitable NbS Measures and Alternatives for Eco-safe Rural Roads

After identifying key issues (step 1) and setting up the main objective and any possible negative or positive impacts (step 2), the next important step (step 3) is to identify the types of $\mathrm{NbS}$ measures that are appropriate [42]. Various types of green or grey/hybrid measures may provide multiple benefits that need to be identified and compared with the benefits from alternative solutions. In order to better understand the optimum benefit of selected solutions (i.e., green, gray, or hybrid), cost-benefit analysis (CBA) should be performed. In some cases, however, the CBA analysis alone may not adequately address the multiple benefits of $\mathrm{NbS}$. For this reason, Raymond et al. [42] suggested participatory assessment, group modeling, and sustainability assessment. The mapping of multiple benefits and how they change over time is also required to be assessed [66] while selecting the $\mathrm{NbS}$ for eco-safe rural roads.

The research conducted in the Panchase geographic region explored the usefulness of perennial local and non-local grass species, among which Amriso (T. maxima), Urlo-Khar (C. microtheca), Napier (P. purpurreum), Salim-Khar (C. gryllus), Kans (S. spontaneum), Kush (C. indica), and Babiyo (E. binate) were local, and Vetiver (C. zizanioides) was the only non-local grass species used in the research. The usefulness of the plant species, in terms of their KPIs for soil slope reinforcement and co-benefits (e.g., economic and livelihood values), was assessed through the test plots (i.e., demonstration sites and rhizotrons) and through community consultations.

The research successfully identified hybrid-type eco-engineering measures suitable for roadside slope protection (Figures 8 and 9). Hybrid eco-engineering is one type of $\mathrm{NbS}$ that includes the construction of roadside and cross drainage, shallow stone walls/retaining walls, stone rip-rap surface drainage, and the plantation of species such as Broom grass (T. maxima) and Vetiver (C. zizanioides) on the roadside slopes, as these species were observed to be useful in terms of root depth, root strength, and above- and below-ground biomass, thereby leading to better root cohesion. Yet, in Nepal, more research needs to be conducted to better understand the KPIs of other grass, shrub, and tree species available in the region and their mechanical and hydrological contributions to slope stability. 

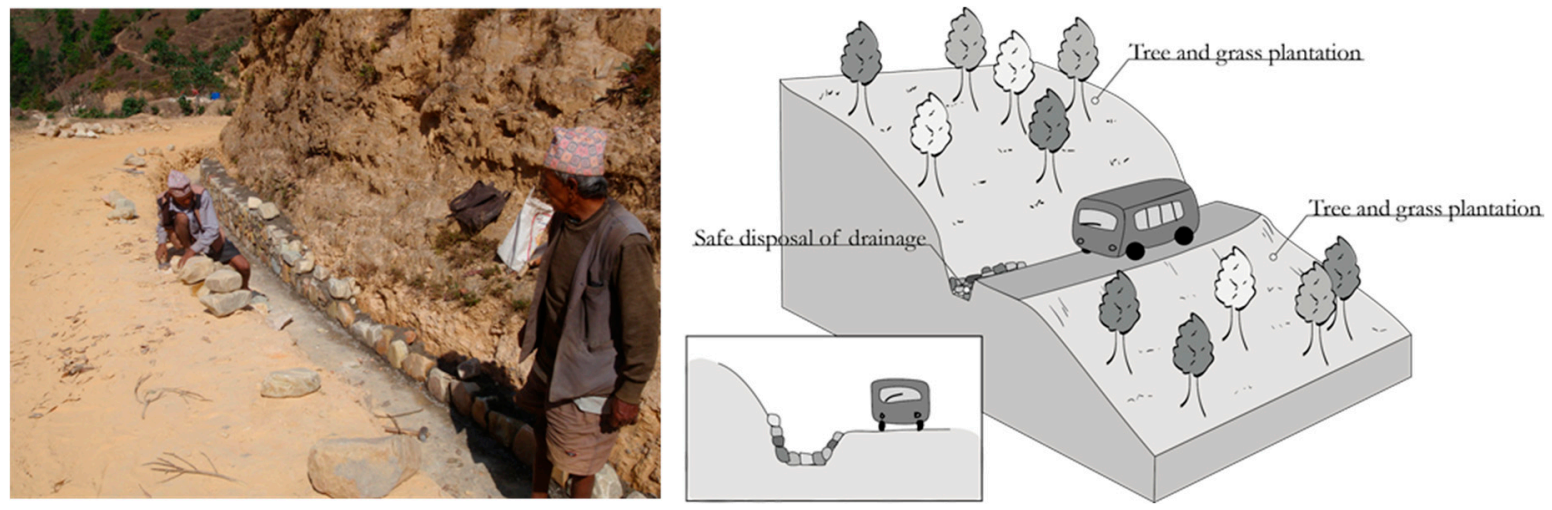

Figure 8. (Left) Example of roadside drainage construction in Bhatkhola demonstration site in Syangja;

(Right) schematic illustrations of drainage works along the road [57].
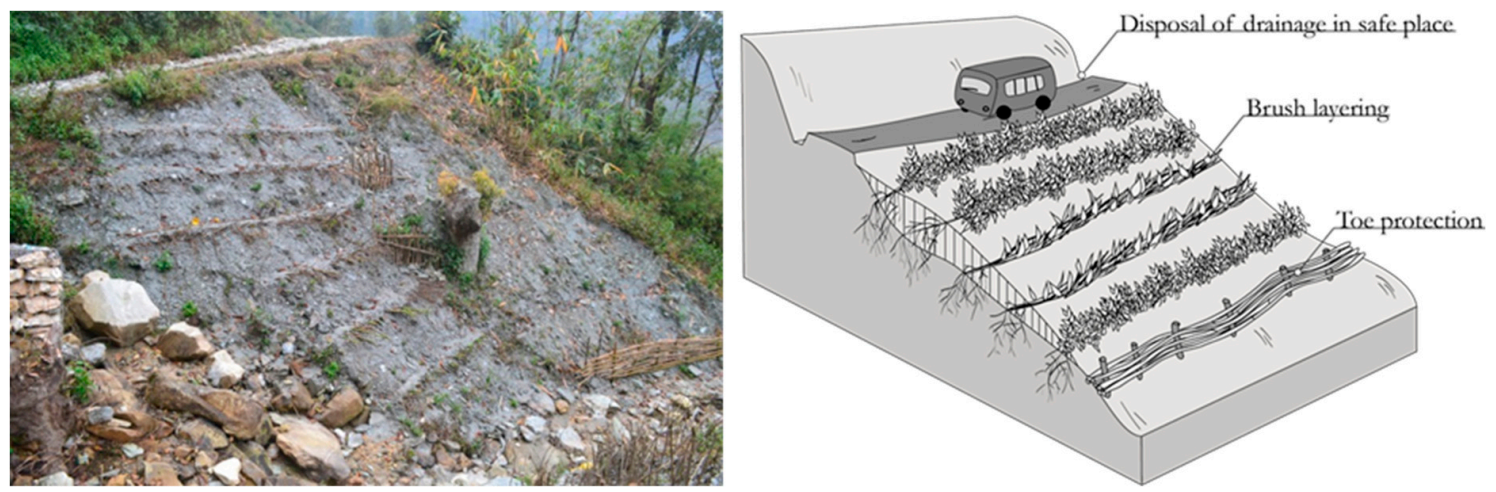

Figure 9. (Left) Example of soil bioengineering along roadside in Tilahar demonstration site in Parbat District, Nepal; (Right) schematic illustration of brush layering [57].

Step 4: Implement the Eco-Safe Rural Road Plan

The implementation of "eco-safe rural roads plan" requires the integration of different types of knowledge such as civil engineering, geotechnics, hydro-meteorology, biology, environment, and, importantly, the local knowledge about plant species and climate [39,67]. In addition, the implementation process needs to support openness, transparency in governance processes, and legitimacy of knowledge from citizens, practitioners, and policy stakeholders [39].

The demonstration sites established for conducting this research in Panchase region indicated that the selected eco-engineering measures can be implemented successfully utilizing local knowledge provided by community members and by ensuring a close dialogue with the local government and other stakeholders. Community members have expert knowledge about their land, climate, and plant species. The RUG, which was described in Section 2, was critical for establishing ownership of the demonstration sites, and the local government demonstrated interest in expanding the eco-engineering measures for extended the length of the rural road in the Panchase region.

\section{Step 5: Establish Awareness and Communication Plan}

Once the eco-safe road implementation plan is agreed upon by engaging the multi-disciplinary teams, the next step is to prepare for the action plans. Implementation should consider the relative costs and benefits of a given action, as well as managing the difficulties relating to uncertainty [42]. There are several stakeholder perceptions and challenges that need to be managed during the implementation of the plan, for which community awareness and communication with the concerned stakeholder is important. This means communicating the co-benefits to different levels of decision-makers and community members throughout the entire lifespan of the project [42]. Proper communication among different interest groups, stakeholders, policy- and decision-makers, and the local population is 
important and effective when realized through a series of parallel and overlapping top-down and bottom-up approaches that help anticipate and correct any negative impacts that may result from the eco-safe road implementation [36].

For example, while exploring the opportunity of implementing the "eco-safe" roadside demonstration activities in the Panchase region, at first, several community members were not convinced. They were more in favor of larger gray measures, such as gabion walls. However, during discussions and meetings through clear and transparent communication the concept and co-benefits for livelihoods were better understood. This helped community members to understand the importance of "NbS and eco-safe roads" and $\mathrm{NbS}$ in the region and increase their interest and participation. Community members actively participated in every step of the research work. In addition, as a part of capacity development, soil bioengineering training was provided to the RUG members, and a community-based soil bioengineering manual (e.g., Devkota et al. (2014) [57]) for the "eco-safe road" was prepared and translated into Nepali language. The manual was distributed to the RUG members and other interest groups.

\section{Step 6: Mobilize the Community for Implementation and Upscaling}

Communities are critical for sustainable implementation of an eco-safe road strategy at the community level. After the dialogue process created awareness about the benefits of the $\mathrm{NbS}$ measures, the communities mobilized members to participate in the field activities. Community members with specific skills were assigned various responsibilities, such as collection of suitable plant species, land development, and construction of simple civil engineering measures (e.g., roadside drainage, toe wall construction, etc.). The engagement of the community members in establishing the demonstration sites was voluntary, inter-disciplinary, and participatory, without any discrimination on the basis of ethnicity or gender.

After the successful establishment of the three demonstration sites in collaboration with the local community and the government in the Panchase region, different interest groups (e.g., NGOs) and the local government demonstrated their interest in expanding and upscaling the "eco-safe roads" approach in their communities. Community members and RUGs started reporting rural roadside slope failures to the local government and insisted on their support in implementing and expanding eco-engineering measures.

\section{Step 7: Establish Monitoring and Evaluation Plan and Follow-Up}

Monitoring of NbS activities for "eco-safe roads" observes the system characteristics after the implementation and collects evidence on the way eco-engineering measures perform in practice [35,42]. The difference between expected and actual outcomes sheds light on the system's response. The interventions should be reviewed and adjusted to respond to challenges or to potential new needs, while the evaluation phase can also lead to corrective action to safeguard the long-term effectiveness of the measure $[35,68]$. Long-term monitoring should lead to new insights into eco-engineering functioning and active learning-even from failure-which can help improve future "eco-safe road" implementation plans [69]. Evaluation relates to the numerous ways of assessing the direct and co-benefits (and costs) of "eco-safe road" within and across challenge areas (i.e., rural roadside slope failure) and within different stages of implementation [42].

Indicators of the performance of "eco-safe roads" cover a range of aspects such as integrated environmental performance, participation of RUGs in the maintenance, effectiveness of the measures in stabilizing the roadside slopes, and transferability of "eco-safe road" actions. Indicators may also relate to the administrative budget and staff allocated for the "eco-safe road" monitoring and implementation of the projects [42,68]. Indicators that quantify the cost-benefit in addition to the involvement of stakeholders can enable a cost-added value quantification, as demonstrated by Connop et al. (2016) [69]. 
In the case of the "eco-safe rural road" demonstration research project in the Panchase region, the performance of the chosen $\mathrm{NbS}$ (i.e., eco-engineering) was assessed scientifically and through public consultation, using FGDs and KIIs at the local level. The performance of the plant species was evaluated and quantified scientifically. The variables were used to establish a multi-criterion-based PCA model, and co-benefits were evaluated qualitatively (e.g., high, medium, and low). While performing the FGDs and KIIs at the end of the project (i.e., fifth year of the project), the response was encouragingly high to medium as demonstrated by the strong performance of plant species used in eco-engineering demonstration plots. In addition, the communities accepted the technique because of very tangible co-benefits, especially after the roads became practicable year-round and they were able to utilize the grasses for economic purposes. The local government stakeholders, on the other hand, were inspired by the eco-engineering measures as being cost-effective and effective for rural roadside slope protection.

In addition, the demonstration sites were visited by national and international experts, policy-makers, and the media [70] at different stages of the research project, and positive responses were received about the adopted methodology and performance of the selected eco-engineering techniques. Finally, the research project was evaluated by an international expert [71], who reported that the community-based "eco-safe road" initiatives were highly successful in terms of addressing the challenges and expectations.

\section{Conclusions}

Roads are important infrastructures that bring livelihood opportunities and improve the quality of life. However, unplanned and non-engineered rural roads are the cause of disasters such as landslides [4]. In Nepal, the problem of unplanned and non-engineered rural roads is pervasive, as such roads are often non-operational for 4-6 months during and after the monsoon period (June-November) [4,20]. These roads are causal factors for landslides and soil erosion, while intense monsoonal rain is known to be the triggering factor damaging the lives and livelihoods, and degrading the environment and ecosystem services [3]. In parallel, landslides cause human suffering and waste economic resources by damaging and blocking roads, as well as restricting rural communities in accessing healthcare, education, and resources. At the present time, the government is not able to adequately address this widespread problem due to limited resources and capacities. It is now important to bring "eco-safe roads", eco-engineering and $\mathrm{NbS}$ into mainstream development activities as sustainable solutions to disasters and climate risks.

Although soil bioengineering is popular in Nepal, and many useful manuals and handbooks were developed in the past three decades, in practice, it has not become mainstream, especially for local community-built roads. Importantly, there is no comprehensive assessment framework for sustainable rural roadside slope protection. The proposed "eco-safe road" framework demonstrated the underlying causes of slope failure and outlined the process to be followed while undertaking eco-engineering measures for safer and sustainable rural roads in the hills of Nepal. Data required for defining the underlying problems of rural roadside slope failure were also discussed through the research and case study described in this article. The "eco-safe rural road" approach demonstrated in the three locations (Gharelu in Kaski, Tilahar in Parbat, and Bhatkhola in Syangja) was accepted by the local communities, because of the depicted results and co-benefits. Moreover, the local government representatives showed their interest, as the techniques which were demonstrated are cost-effective and sustainable. The eco-engineering approaches described through this research can be expanded to other similar geographic regions of the country, for which this framework can be used as a guideline for the successful implementation of eco-engineering measures.

The upscaling of "eco-safe rural roads" can be possible during the demonstration stage, as well as during the mainstreaming phase when teams learn from the project demonstrations [42]. During the demonstration phase, upscaling can contribute to strengthening government, stakeholder, and investor confidence [72], while increasing the number of "eco-safe roads" implementation projects 
and co-benefits. This requires multi-actor partnerships [73]. Scientists can provide the evidence to predict the benefits of "eco-safe roads", while societal stakeholders can be instrumental in informing key implementation issues, for example, finding suitable locations for "eco-safe road" [69]. Finally planners can contribute to developing innovative ways to systematically incorporate various types of eco-engineering and $\mathrm{NbS}$ into governance instruments and regulations.

Author Contributions: The eco-safe rural road assessment framework is part of the PhD thesis entitled "Climate-Induced Disasters-Prospective of Eco-Engineering in Building Resilient Mountain Communities in the Central-Western Nepal Hills" by S.D., who identified and conceptualized the issues of eco-safe rural roads in the hills of Nepal, established the demonstration sites and rhizotrons, and assessed the plant contribution in reinforcing the soil slope, as well as developing the LSM, establishing inventories of landslides and rural roads, and drafting the framework. N.M.S., as an immediate supervisor, revisited the draft framework and provided critical feedback, while K.S.-R. refined the write-up and cross-verified the references.

Funding: This framework is the outcome of IUCNs Ecosystem Protecting Infrastructures and Communities (EPIC) project for which funding was provided by the Federal Ministry for the Environment, Nature Conservation, Building, and Nuclear Safety (BMUB), Government of Germany.

Acknowledgments: We would like to acknowledge IUCN EPIC and BMUB, Government of Germany, for providing this research opportunity and grant support to the Institute of Engineering, Department of Civil Engineering, Tribhuvan University, Nepal. The authors would like to thank Alexia Stokes and Zhun Mao, French National Institute for Agricultural Research; Brian G. McAdoo, Yale NUS College, Singapore; Michel Jaboyedoff, Institute of Earth Science, University of Lausanne, Switzerland; and Purna Chandra Lal Rajbhandari, independent researcher, Kathmandu for providing support, feedback on the draft manuscripts, and encouragement. We would like to acknowledge the contribution from the local community, support from the local government in the Panchase region, and different research institutions, professionals, and experts while conducting this research.

Conflicts of Interest: The authors declare no conflicts of interest.

\section{References}

1. UNDP. Proceedings of Nepal Country Workshop on Environments of the Poor in the Context of Climate Change and the Green Economy July 2011; Government of Nepal, National Planning Comission, UNDP and UNEP: Kathmandu, Nepal, 2011.

2. UNDP. Economic Analysis of Local Government Investment in Rural Roads in Nepal; LGCDP, UNDP, UNEP: Kathmandu, Nepal, 2011.

3. McAdoo, B.G.; Quak, M.; Gnyawali, K.R.; Adhikari, B.R.; Devkota, S.; Rajbhandari, P.L.; Sudmeier-Rieux, K. Roads and landslides in Nepal: How development affects environmental risk. Nat. Hazards Earth Syst. Sci. 2018, 18, 3203-3210. [CrossRef]

4. Sudmeier-Rieux, K.; McAdoo, B.G.; Devkota, S.; Rajbhandari, P.C.L.; Howell, J.; Sharma, S. Invited perspectives: Mountain roads in Nepal at a new crossroads. Nat. Hazards Earth Syst. Sci. 2019, 19, 655-660. [CrossRef]

5. Koirala, G.P. Economic Analysis of Local Government Investments in Rural Roads: Reducing Poverty through Managing Climate and Environment Risks. In Environments of the Poor in the Context of Climate Change and the Green Economy; Government of Nepal: Kathmandu, Nepla, 2011.

6. Jaboyedoff, M.; Michoud, C.; Derron, M.-H.; Voumard, J.; Leibundgut, G.; Sudmeier-Rieux, K.; Nadim, F.; Nadim, F.; Leroi, E. Human-induced landslides: Toward the analysis of anthropogenic changes of the slope environment. In Landslides and Engineered Slopes. Experience, Theory and Practice; CRC Press: Boca Raton, FL, USA, 2016.

7. Petley, D.N. On the impact of climate change and population growth on the occurrence of landslides in Asia. Q. J. Eng. Geol. Hydrogeol. 2010, 43, 487-496. [CrossRef]

8. Dahal, R.K.; Hasegawa, S.; Masuda, T.; Yamanaka, M. Roadside slope failures in Nepal during torrential rainfall and their mitigation. In Disaster Mitigation of Debris Flows, Slope Failures and Landslides; Universal Academy Press, Inc.: Tokyo, Japan, 2006; pp. 503-514.

9. Laban, P. Landslide Occurrence in Nepal; Working Papar No. 13; Integrated Watershed Management Project: Kathmandu, Nepal, 1979.

10. DOR. National Transportation Policy Ministry of Physical Planning and Works, 2058 (2001/2002); Government of Nepal: Kathmandu, Nepal, 2002; p. 15.

11. DOR. Road Network Data; Roads, D.o., Ed.; Government of Nepal: Kathmandu, Nepal, 2017; p. 17. 
12. Petley, D.N.; Hearn, G.J.; Hart, A.; Rosser, N.; Dunning, S.; Oven, K.; Mitchell, W.A. Trends in Landslide occurrence in Nepal. Nat. Hazards 2007, 43, 23-44. [CrossRef]

13. BBC. Nepal: Landslides Triggers by Rain Kill at Least 29 People. Available online: https://www.bbc.com/ news/world-asia-33714147 (accessed on 15 August 2015).

14. IUCN. Geological Assessment of Dunde Landslide/Debris Flows and Identifying Ecosystem Based Mitigation Measures; IUCN: Lalitpur, Nepal, 2016; p. 105.

15. DesInventar. Nepal Disaster Profile. Available online: http://www.desinventar.net/DesInventar/profiletab. jsp? countrycode=npl (accessed on 29 April 2019).

16. Reliefweb. NEPAL: Road-Building Leads to Deadlier Landslides. Available online: https://reliefweb.int/ report/nepal/nepal-road-building-leads-deadlier-landslides (accessed on 29 April 2019).

17. Guragai, J., Sr.; Divisional Engineer, Department of Local Infrastructures (DoLI), Government of Nepal, Kathmandu, Nepal. Personal Communication, 2019.

18. Devkota, S.; Sudmeier-Rieux, K.; Adhikari, A.; Khanal, R.; Penna, I.; Jaboyedoff, M. Investing in Ecosystem Aproach for more resilient Disaster Risks Reduction: The case eco-safe roads in Nepal. In FIG-ISPRS Workshop 2015: International Workshop on Role of Land Professionals and SDI in Disaster Risk Reduction in the Context of Post 2015 Nepal Earthquake, Kathmandu, Nepal, 25-27 November 2015; Department of Survey: Kathmandu, Nepal, 2015; p. 13.

19. Sudmeier-Rieux, K.; Jaquet, S.; Derron, M.-H.; Jaboyedoff, M.; Devkota, S. A Case Study of Landslides and Coping Strategies in Two Villages of Central-Eastern Nepal. J. Appl. Geogr. 2011, 32, 680-690. [CrossRef]

20. World Bank. Nepal Road Sector Assessment Study; Government of Nepal, World Bank, Asian Development Bank, DFID, SDC: Kathmandu, Nepal, 2012; p. 55.

21. Gray, D.H.; Sotir, R.B. Biotechnical and Soil Bioengineering Slope Stabilization: A Practical Guide for Erosion Control; John Wiley \& Sons: Hoboken, NJ, USA, 1996.

22. Dhital, Y.P.; Kayastha, R.B.; Shi, J. Soil bioengineering application and practices in Nepal. Environ. Manag. 2013, 51, 354-364. [CrossRef] [PubMed]

23. Howell, J. Application of bio-engineering in slope stabilization: Experience from Nepal. In Landslide Hazard Mitigation in the Hindu Kush-Himalayas; Tianchi, L., Chalise, S., Upreti, B.N., Eds.; International Centre for Integrated Mountain Development (ICIMOD): Kathmandu, Nepal, 2001; p. 15.

24. Rizvi, A.R.; Baig, S.; Verdone, M. Ecosystems Based Adaptation: Knowledge Gaps in Making an Economic Case for Investing in Nature Based Solutions for Climate Change; IUCN: Gland, Switzerland, 2015; p. 48.

25. Stokes, A.; Sotir, R.; Chen, W.; Ghestem, M. Soil bio-and eco-engineering in China: Past experience and future priorities. Ecol. Eng. 2010, 36, 247-257. [CrossRef]

26. Norris, J.E.; Stokes, A.; Mickovski, S.B.; Cammeraat, E.; van Beek, R.; Nicoll, B.C.; Achim, A. Slope Stability and Erosion Control: Ecotechnological Solutions; Springer: Dordrecht, The Netherlands, 2008.

27. Faivre, N.; Fritz, M.; Freitas, T.; de Boissezon, B.; Vandewoestijne, S. Nature-Based Solutions in the EU: Innovating with nature to address social, economic and environmental challenges. Environ. Res. 2017, 159, 509-518. [CrossRef] [PubMed]

28. EEA. Exploring Nature-Based Solutions: The Role of Green Infrastructure in Mitigating the Impacts of Weather-and Climate Change-Related Natural Hazards; European Environment Agency, Publications Office of the European Union: Luxembourg, 2015; p. 66.

29. Lafortezza, R.; Chen, J.; van den Bosch, C.K.; Randrup, T.B. Nature-based solutions for resilient landscapes and cities. Environ. Res. 2018, 165, 431-441. [CrossRef]

30. Maes, J.; Jacobs, S. Nature-based solutions for Europe's sustainable development. Conserv. Lett. 2017, 10, 121-124. [CrossRef]

31. Mickovski, S.; Thomson, C. Developing a framework for the sustainability assessment of eco-engineering measures. Ecol. Eng. 2017, 109, 145-160. [CrossRef]

32. Mickovski, S.B. Why is the future ready for Environmental Geotechnics. Environ. Geotech. 2016, 3, 63-64. [CrossRef]

33. Young, R.; Zanders, J.; Lieberknecht, K.; Fassman-Beck, E. A comprehensive typology for mainstreaming urban green infrastructure. J. Hydrol. 2014, 519, 2571-2583. [CrossRef]

34. Bennett, E.M.; Cramer, W.; Begossi, A.; Cundill, G.; Díaz, S.; Egoh, B.N.; Geijzendorffer, I.R.; Krug, C.B.; Lavorel, S.; Lazos, E.; et al. Linking biodiversity, ecosystem services, and human well-being: Three challenges for designing research for sustainability. Curr. Opin. Environ. Sustain. 2015, 14, 76-85. [CrossRef] 
35. Calliari, E.; Staccione, A.; Mysiak, J. An assessment framework for climate-proof nature-based solutions. Sci. Total Environ. 2019, 656, 691-700. [CrossRef]

36. Santoro, S.; Pluchinotta, I.; Pagano, A.; Pengal, P.; Cokan, B.; Giordano, R. Assessing stakeholders' risk perception to promote Nature Based Solutions as flood protection strategies: The case of the Glinščica river (Slovenia). Sci. Total Environ. 2019, 655, 188-201. [CrossRef]

37. van Wesenbeeck, B.; IJff, S.; Jongman, B.; Balog, S.; Kaupa, S.; Bosche, L.; Lange, G.M.; Holm-Nielsen, N.; Nieboer, H.; Taishi, Y.; et al. Implementing Nature Based Flood Protection: Principles and Implementation Guidance; World Bank Group: Washington, DC, USA, 2017.

38. European Commission. Nature-Based Solutions. Available online: https://ec.europa.eu/research/ environment/index.cfm?pg=nbs (accessed on 10 May 2014).

39. Nesshöver, C.; Assmuth, T.; Irvine, K.N.; Rusch, G.M.; Waylen, K.A.; Delbaere, B.; Haase, D.; Jones-Walters, L.; Keune, H.; Kovacs, E.; et al. The science, policy and practice of nature-based solutions: An interdisciplinary perspective. Sci. Total Environ. 2017, 579, 1215-1227. [CrossRef]

40. Cariñanos, P.; Calaza-Martínez, P.; O’Brien, L.; Calfapietra, C. The cost of greening: Disservices of urban trees. In The Urban Forest-Cultivating Green Infrastructure for People and the Environment; David, P., Carlo, C., Roeland, S., Liz, O.B., Silvija, K.O., Giovanni, S., Rocío, A.d.A., Eds.; Springer International Publishing AG: Berlin/Heidelberg, Germany, 2017; Volume 7, p. 9.

41. Bauduceau, N.; Berry, P.; Cecchi, C.; Elmqvist, T.; Fernandez, M.; Hartig, T.; Krull, W.; Mayerhofer, E.; Sandra, N.; Noring, L.; et al. Towards an EU Research and Innovation Policy Agenda for Nature-Based Solutions $\mathcal{E}$ Re-Naturing Cities: Final Report of the Horizon 2020 Expert Group on 'Nature-Based Solutions and Re-naturing Cities'; Publications Office of the European Union: Brussels, Belgium, 2015.

42. Raymond, C.M.; Frantzeskaki, N.; Kabisch, N.; Berry, P.; Breil, M.; Nita, M.R.; Geneletti, D.; Calfapietra, C.; et al. A framework for assessing and implementing the co-benefits of nature-based solutions in urban areas. Environ. Sci. Policy 2017, 77, 15-24. [CrossRef]

43. Mao, Z.; Bourrier, F.; Stokes, A.; Fourcaud, T. Three-dimensional modelling of slope stability in heterogeneous montane forest ecosystems. Ecol. Model. 2014, 273, 11-22. [CrossRef]

44. MacNeil, D.J.; Steele, D.P.; McMahon, W.; Carder, D.R. Vegetation for Slope Stability; Prepared for Quality Services, Civil Engineering, Highways Agency; TRL: Wokingham, UK, 2001.

45. Truong, P. Vetiver System for Infrastructure Protection; Veticon Consulting: Brisbane, Australia, 2000; Volume 108, p. 11.

46. Petrone, A.; Preti, F. Soil bioengineering for risk mitigation and environmental restoration in a humid tropical area. Hydrol. Earth Syst. Sci. 2010, 14, 239-250. [CrossRef]

47. Wu, T.H.; McKinnell, W.P., III; Swanston, D.N. Strength of tree roots and landslides on Prince of Wales Island, Alaska. Can. Geotech. J. 1979, 16, 19-33. [CrossRef]

48. Bohm, W. Methods of Studying Root Systems; Springer: Berlin/Heidelberg, Germany; New York, NY, USA, 1979.

49. Pohl, M.; Stroude, R.; Buttler, A.; Rixen, C. Functional traits and root morphology of alpine plants. Ann. Bot. 2011, 108, 537-545. [CrossRef] [PubMed]

50. Bro, R.; Smilde, A.K. Principal component analysis. Anal. Methods 2014, 6, 2812-2831. [CrossRef]

51. Chae, B.-G.; Lee, J.-H.; Park, H.-J.; Choi, J. A method for predicting the factor of safety of an infinite slope based on the depth ratio of the wetting front induced by rainfall infiltration. Nat. Hazards Earth Syst. Sci. 2015, 15, 1835-1849. [CrossRef]

52. Remondo, J.; González, A.; De Terán, J.R.D.; Cendrero, A.; Fabbri, A.; Chung, C.-J.F. Validation of Landslide Susceptibility Maps; Examples and Applications from a Case Study in Northern Spain. Nat. Hazards 2003, 30, 437-449. [CrossRef]

53. Deng, X.; Li, L.; Tan, Y. Validation of Spatial Prediction Models for Landslide Susceptibility Mapping by Considering Structural Similarity. Int. J. Geo-Inf. 2017, 6, 10. [CrossRef]

54. Devkota, S.; Shakya, N.; Sudmeier-Rieux, K.; Jaboyedoff, M.; Van Westen, C.; Mcadoo, B.; Adhikari, A. Development of Monsoonal Rainfall Intensity-Duration-Frequency (IDF) Relationship and Empirical Model for Data-Scarce Situations: The Case of the Central-Western Hills (Panchase Region) of Nepal. Hydrology 2018, 5, 27. [CrossRef] 
55. Devkota, S.; Shakya, N.M.; Sudmeier-Rieux, K.; McAdoo, B.G.; Jaboyedoff, M. (Eds.) Predicting soil depth to bedrock in an anthropogenic landscape: A case study of Phewa Watershed in Panchase region of Central-Western Hills, Nepal. In Proceedings of the 11th IAEG Asian Regional Conference (ARC-11)—Engineering geology for Geodisaster Management, Kathmandu, Nepal, 28-30 November 2017; Nepal geological Society: Kathmandu, Nepal, 2018.

56. Dingman, S.L. Physical Hydrology; Prentice Hall: Upper Saddle River, NJ, USA, 2002; p. 646.

57. Devkota, S.; Sudmeier-Rieux, K.; Penna, I.; Eberle, S.; Jaboyedoff, M.; Adhikari, A.; et al. Community-Based Bio-Engineering for Eco-Safe Roads in Nepal; University of Lausanne: Lausanne, Switzerland; International Union for Conservation of Nature: Gland, Switzerland; Nepal and Department of Soil Conservation and Watershed Management: Kathmandu, Nepal; Government of Nepal: Kathmandu, Nepal, 2014; p. 95.

58. Howell, J. Roadside Bio-Engineering: Reference Manual; Omar, S., Ed.; Department of Roads, Government of Nepal: Kathmandu, Nepal, 1999; p. 216.

59. Howell, J. Roadside Bio-Engineering: Site Handbook; Omar, S., Ed.; Department of Roads, Government of Nepal: Kathmandu, Nepal, 1999; p. 160.

60. ORCDC. Vetiver Grass Installation Guide: Pacific Islands Area; Oahu Resource Conservation and Development Council in cooperation with USDA Natural Resource Conservation Service (NRCS): Kunia Camp, HI, USA, 2012.

61. Larsen, M.C. Rainfall-triggered landslides, anthropogenic hazards and mitigation strategies. Adv. Geosci. 2008, 14, 147-153. [CrossRef]

62. Vuillez, C.; Tonini, M.; Sudmeier-Rieux, K.; Devkota, S.; Derron, M.-H.; Jaboyedoff, M. Land use changes, landslides and roads in the Phewa Watershed, Western Nepal from 1979 to 2016. Appl. Geogr. 2018, 94, 30-40. [CrossRef]

63. DMG. Cartographer Engineering and Environmental Geologicla Map of Pôkhara Valley; Government of Nepal: Kathmandu, Nepal, 2002.

64. Devkota, B.; Paudel, P.; Omura, H.; Kubota, T.; Morita, K. Uses of vegetative measures for erosion mitigation in Mid Hill areas of Nepal. Kyushu J. For. Res. 2006, 59, 265-268.

65. Karki, R.; Schickhoff, U.; Scholten, T.; Böhner, J. Rising precipitation extremes across Nepal. Climate 2017, 5, 4. [CrossRef]

66. Fernandes, J.P.; Guiomar, N. Nature-based solutions: The need to increase the knowledge on their potentialities and limits. Land Degrad. Dev. 2018, 29, 1925-1939. [CrossRef]

67. Stokes, A.; Douglas, B.G.; ourcaud, F.T.; Giadrossich, F.; Gillies, C.; Hubble, T.; Kim, J.H.; Loades, K.W.; Mao, Z.; McIvor, I.R.; et al. Ecological mitigation of hillslope instability: Ten key issues facing researchers and practitioners. Plant Soil 2014, 377, 1-23. [CrossRef]

68. Kabisch, N.; Frantzeskaki, N.; Pauleit, S.; Naumann, S.; Davis, M.; Artmann, M.; Haase, D.; Knapp, S.; Korn, H.; Stadler, J.; et al. Nature-based solutions to climate change mitigation and adaptation in urban areas: Perspectives on indicators, knowledge gaps, barriers, and opportunities for action. Ecol. Soc. 2016, 21, 39. [CrossRef]

69. Connop, S.; Vandergert, P.; Eisenberg, B.; Collier, M.J.; Nash, C.; Clough, J.; Newport, D. Renaturing cities using a regionally-focused biodiversity-led multifunctional benefits approach to urban green infrastructure. Environ. Sci. Policy 2016, 62, 99-111. [CrossRef]

70. Kathmandupost. Eco-Safe Roads. Available online: https://kathmandupost.ekantipur.com/news/2016-10-02/ eco-safe-roads.html (accessed on 9 May 2019).

71. Miththapala, S. EPIC External Review; International Union for Conservaiton of Nature (IUCN): Gland, Switzerland, 2017; p. 259.

72. Cohen-Shacham, E.; Walters, G.; Janzen, C.; Maginnis, S. Nature-Based Solutions to Address Global Societal Challenges; IUCN: Gland, Switzerland, 2016; p. 97.

73. Frantzeskaki, N.; Borgström, S.; Gorissen, L.; Egermann, M.; Ehnert, F. Nature-Based Solutions Accelerating Urban Sustainability Transitions in Cities: Lessons from Dresden, Genk and Stockholm Cities. In Nature-Based Solutions to Climate Change Adaptation in Urban Areas; Springer: Berlin/Heidelberg, Germany, 2017; pp. 65-88.

(C) 2019 by the authors. Licensee MDPI, Basel, Switzerland. This article is an open access article distributed under the terms and conditions of the Creative Commons Attribution (CC BY) license (http://creativecommons.org/licenses/by/4.0/). 